ARTICLE OPEN

\title{
Tri-phasic engineered wetland system for effective treatment of azo dye-based wastewater
}

\author{
Dileep Kumar Yeruva ${ }^{1,2}$, Palle Ranadheer ${ }^{1}$, A. Kiran Kumar ${ }^{1}$ and S. Venkata Mohan ${ }^{1,2}$
}

Synthetic dyes are a major class of compounds used in the textile industry. The effluents released from these industries are carcinogenic and mutagenic in nature and pose potential threat to all life forms. Here, we designed a novel tri-phasic engineered flow through wetland system (TEWS) with three specific microenvironments (tri-phasic aquatic systems) integrated in a defined sequence to effectively treat azo dye-based textile wastewater. Tank 1 with free-floating and emergent aquatic macrophytes create anaerobic/anoxic microenvironments and facilitate reduction of the azo dye molecules. Tank 2 consists of submerged macrophytes which create an aerophilic microenvironment that direct the oxidation of carbon compounds along with nitrification. Tank 3 with free-floating plants and aquatic animals acts as filter feeder intended to remove suspended solids and colour, as well as residual carbon. The strategically designed TEWS attributes to $76 \% / 87 \%$ of dye/chemical oxygen demand removal. The morphological toxicity test of plants and fishes illustrate the nontoxic nature of treated effluents. Thus, TEWS not only decolorizes the azo dye but also removes its toxic and mutagenic components.

npj Clean Water (2019)2:13; https://doi.org/10.1038/s41545-019-0037-y

\section{INTRODUCTION}

Azo dyes represent a major class of colorants used in textile industries that contain one or more azo bonds $(-\mathrm{N}=\mathrm{N}-)$. The high color intensity is generally attributed due to the azo bond associated with chromophore. ${ }^{1}$ These dyes are also complex due to substituted aromatic rings associated with different groups, such as chloro $(-\mathrm{Cl})$, methyl $\left(-\mathrm{CH}_{3}\right)$, nitro $\left(-\mathrm{NO}_{2}\right)$, amino $\left(-\mathrm{NH}_{2}\right)$, hydroxyl $(-\mathrm{OH})$, and carboxyl $(-\mathrm{COOH})$ groups. ${ }^{2}$ Azo dyes get decolourized by splitting the azo bonds in sequential bio-redox conditions, forming aromatic amines and further breakdown into simpler compounds. ${ }^{3-5}$ The azo bonds are environmentally electrophilic in nature and can accept the electrons from the reductive conditions to cleave the azo bond and form the aromatic amines and then breakdown into nontoxic chemicals. ${ }^{6-8}$ The anaerobic digestion of azo dyes form aromatic amines that are cytotoxic, mutagenic, or carcinogenic. ${ }^{9-11}$ Thus, these aromatic amines can be mineralized and converted to nontoxic compounds by further subjecting to aerobic treatment with non-specific enzymes through hydroxylation and ring opening of the aromatic compounds. ${ }^{3,12}$ Past few years, several researchers have been working on combined, sequential, or integrated bioreactor strageies. $^{13}$

Plants play significant role in xenobiotic degradation through their complex array of enzymes, than simply providing sites for the development of symbiotic microorganisms. ${ }^{14}$ Plant roots and their associated microbial population may perform physical removal of solids and adsorb the nutrients and dissolved constituents. ${ }^{15,16}$ The plants may create proper microenvironments for the treatment process. These mainly include the large rooted floating plants which allow water to become anaerobic, leading to the nitrification/denitrification. Plant metabolism of xenobiotics may lead to total or partial degradation or transformation by reductive, oxidative or hydrolytic enzymes. Phytoremediation is easier to regulate because it is an autotrophic system that requires minimal nutrient and economic input. Moreover, plants offer protection against water and wind erosion, preventing contaminants from spreading. ${ }^{17}$ Salsola vermiculata, a desert plant, has been proved to be a low-cost option for the removal of large organic molecules. ${ }^{18}$ There have been few field tests to date on constructed wetlands, which have been used to treat the industrial effluents containing a wide range of chemicals. ${ }^{19-23}$

The tri-phasic engineered wetland system (TEWS) was designed as an alternative process to treat the dye-based wastewaters with the aim of complete mineralization using synergistic tropical microenvironments. TEWS is an engineered wetland biosystem designed to consist of three specific microenvironments (tri-trophical aquatic systems) namely freefloating and emergent aquatic macrophytes, submerged macrophytes, and free-floating plants. The constructed wetland mimics a natural ecosystem, wherein all the trophic conditions are balanced and perform their role and in the process bring about wastewater treatment by relying entirely on the living systems. ${ }^{3,24-26}$ TEWS symbiotically enables ecological selfdesign ${ }^{25,27}$ with an ecosystem boundary that can selforganize. ${ }^{25-30}$ The efficiency of designed TEWS mainly depends on the root zone interactions between soil, contaminants, plant roots, and a variety of microorganisms with indigenous tropical microenvironments in each designed tanks. This primary objective is to address the current problems in the field of textile/azo dye industry by specifically providing in situ redox microenvironments with living systems for effective degradation of azo dye.

\footnotetext{
${ }^{1}$ Bioengineering and Environmental Sciences Lab, CEEFF, CSIR-Indian Institute of Chemical Technology (CSIR-IICT), Hyderabad, Telangana 500007, India and ${ }^{2}$ Academy of Scientific and Innovative Research (AcSIR), Ghaziabad, India

Correspondence: S. Venkata Mohan (svmohan@iict.res.in)
}

Received: 25 October 2018 Accepted: 5 May 2019

Published online: 04 June 2019 


\section{RESULTS AND DISCUSSION}

Colour removal

The efficiency of TEWS to remove color was assessed at three tropical levels with $50 \mathrm{mg} / \mathrm{L}$ of dye concentrations at a constant organic (COD) load of $250 \mathrm{mg} / \mathrm{L}$ (Fig. 1). Color removal pattern varied with the function of tank and its associated conditions. Relatively rapid and higher color removal was observed in Tank 1 outlet compared with Tank 2 and Tank 3. On individual tank basis, removal efficiency was $62 \%, 25 \%$, and $17 \%$ in the outlet of Tank 1, Tank 2, and Tank 3, respectively (Fig. 1a, b). Cumulatively three tanks showed a color removal efficiency of $76 \%$. The persistent anoxic microenvironment in Tank 1 favored denitrification that led to the azo bond breakdown of aromatic amines.

UV-Vis spectra depicted reduction of azo group corresponding to peak at $418 \mathrm{~nm}$ in Tank 1 compared with inlet (Fig. 1c). This infers the azo group breakdown followed by a new peak appearance in the range of $340-350 \mathrm{~nm}$, which corresponds to the formation of imine groups $(\mathrm{R}-\mathrm{N}=\mathrm{C}-$ ). The reduction of azo dye resulted in the formation of recalcitrant aromatic amine groups namely tartrazine, producing carcinogenic amines $\left(\mathrm{R}-\mathrm{NH}_{2}\right)$, such as benzidine and 4-aminoaniline ${ }^{31}$, which are cytotoxic, mutagenic, or carcinogenic. Tank 2 due to its self-generation of aerobic microenvironment facilitates nitrification. Aromatic amines get mineralized by non-specific enzymes through hydroxylation and ring-opening structure. The UV-Vis chromatographs attribute the breaking of the aromatic ring with its respective amine, imine, and benzene-derivative groups. The intensity of the IR spectral peak significantly reduced from Tank 1 to Tank 2 at $418 \mathrm{~nm}$ and $350 \mathrm{~nm}$, which depicts the removal of aromatic groups and their derivatives. In Tank 3, the linear UV-Vis spectra represent the total degradation of azo bond and other derived compounds.

FT-IR spectra peaks before and after the treatment of each individual tanks (Fig. 2, Table 1) illustrated the major fraction of $\mathrm{N}-\mathrm{H}$ stretch at peak $3417.77 \mathrm{~cm}^{-1}$ and other $-\mathrm{OH},-\mathrm{CH}$, and other non-specific functional groups at $3417 \mathrm{~cm}^{-1}, 1604 \mathrm{~cm}^{-1}$, $1016.62 \mathrm{~cm}^{-1}$, and $754 \mathrm{~cm}^{-1}$. The major absorption band at $3414.96 \mathrm{~cm}^{-1}$ corresponding to the stretching vibration of $-\mathrm{N}-\mathrm{H}$, diminished after the degradation of dye, moreover a new absorption band at $2518.57 \mathrm{~cm}^{-1}$ corresponding to the $-\mathrm{S}=\mathrm{O}$ stretching was observed. The absorption bands at $1636.86 \mathrm{~cm}^{-1}$ and $1440.21 \mathrm{~cm}^{-1}$ can be assigned to the quinonoid ring and the benzenoid ring, respectively. Bands at $1298 \mathrm{~cm}^{-1}$ and $1150 \mathrm{~cm}^{-1}$ are due to $-\mathrm{C}=\mathrm{N}$ bending and in plane bending of the $-\mathrm{C}=\mathrm{H}$ bond. In comparison with inlet, Tank 1 followed by Tank 2 and Tank 3 treated effluents have showed disappearance of many functional groups with decreased intensity (major peaks).

\section{Azo reductase activity}

The azo reductase (AR) enzyme has the ability to degrade the azo bond in both aerobic and anaerobic conditions. AR enzyme basically functions to cleave azo bonds with the aid of an electron donor (NADH and/or NADPH). This was monitored during operation of different tropical systems with plant extract, suspending microbes, and sediment microbial consortia (Fig. 3). Tank 1 showed higher azo reductase activity in root extract (34.61 units $/ \mathrm{mL}$ ) followed by suspending microbes and sediment bacteria (34.05 and 33.18 units $/ \mathrm{mL}$ ). Whereas Tank 2 and Tank 3 showed 31.13, 32.27, and 30.53 Units $/ \mathrm{mL}$ and 30.93, 32.61, and 30.93 Units/mL microbial azo reductase than plant root azo reductase activity, suspending microbes and sediment bacteria, respectively. In anaerobic microenvironment, aromatic nitro compounds were generated from the action of azo reductase, which later undergoes the nitro reduction reaction mediated by reduced quinone compounds resulting in quinone reductase activity. $^{32-34}$ In aerobic conditions which were eventually degraded by other enzymes like mono, deoxygenasas, and
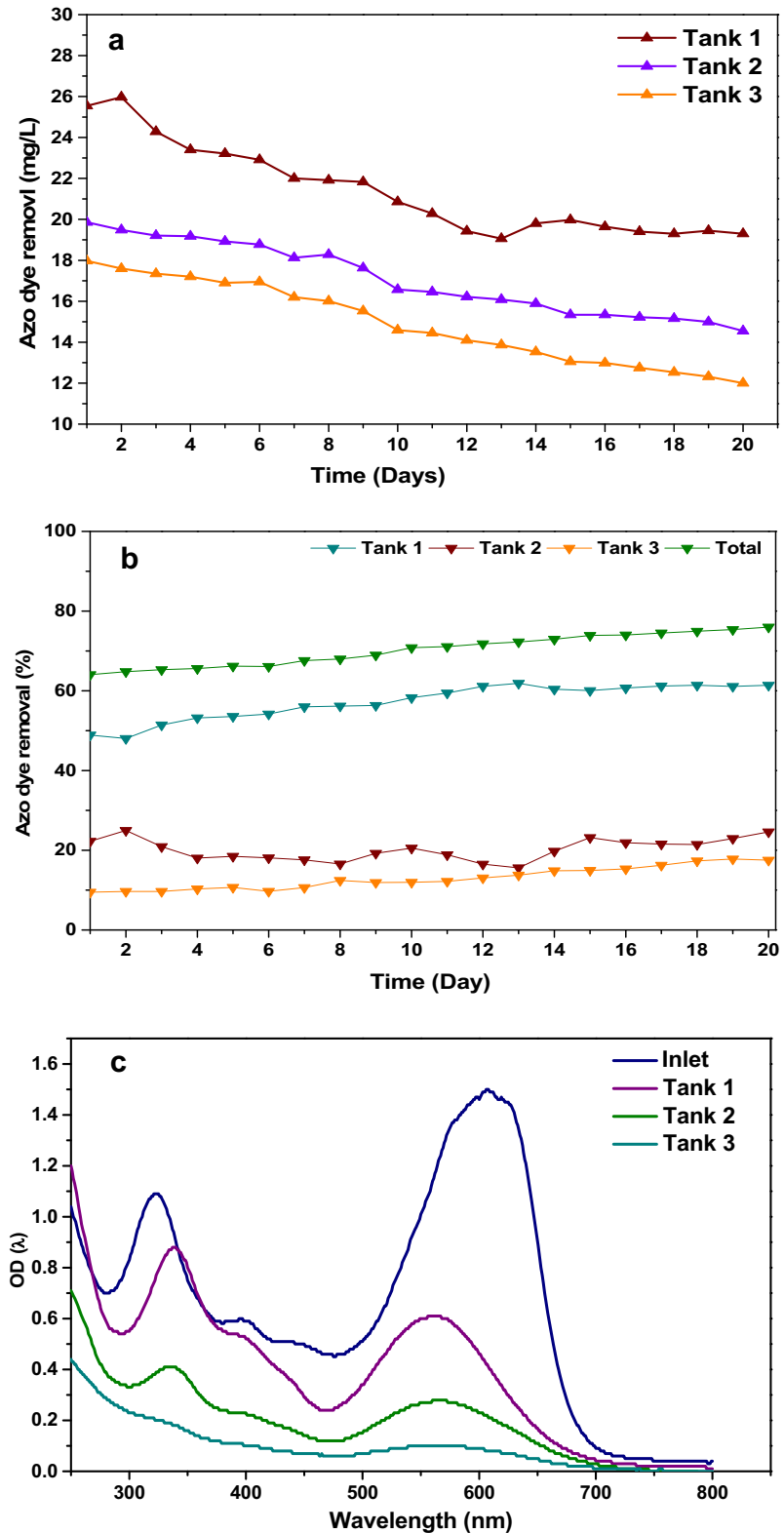

Fig. 1 a, b Variations in azo dye removal concentrations and removal efficiencies in individual tanks with respect to time, c UV-Visible spectra profile of degraded dye compounds in individual tanks

hydrolases, it was demonstrated that menadione (quinone) is a better substrate for flavin-containing $\mathrm{NAD}(\mathrm{P}) \mathrm{H}$-dependent azo reductase compared with azo and nitro compounds. ${ }^{32}$ Therefore, azo, nitro, and quinone reductions could also be another criterion to be considered in azoreductase activity. It was also reported to play an important role of azo reductase in the detoxification of quinones apart from azo bond removal. ${ }^{34}$ The quinone reduction activities of azo reductase from different microorganisms and their dependence on $\mathrm{NAD}(\mathrm{P}) \mathrm{H}$ co-factor need to be classified as $\mathrm{NAD}(\mathrm{P})$ $\mathrm{H}$ quinone oxidoreductases (NQOs). ${ }^{32,35-38}$ It was also identified that the $N A D(P) H$ quinone oxidoreductase activity in azoreductase from $P$. aeruginosa demonstrated that the azoreductases and the $\mathrm{NAD}(\mathrm{P}) \mathrm{H}$ quinone oxidoreductases belong to the same FMNdependent azoreductase superfamily..$^{39-41}$ 

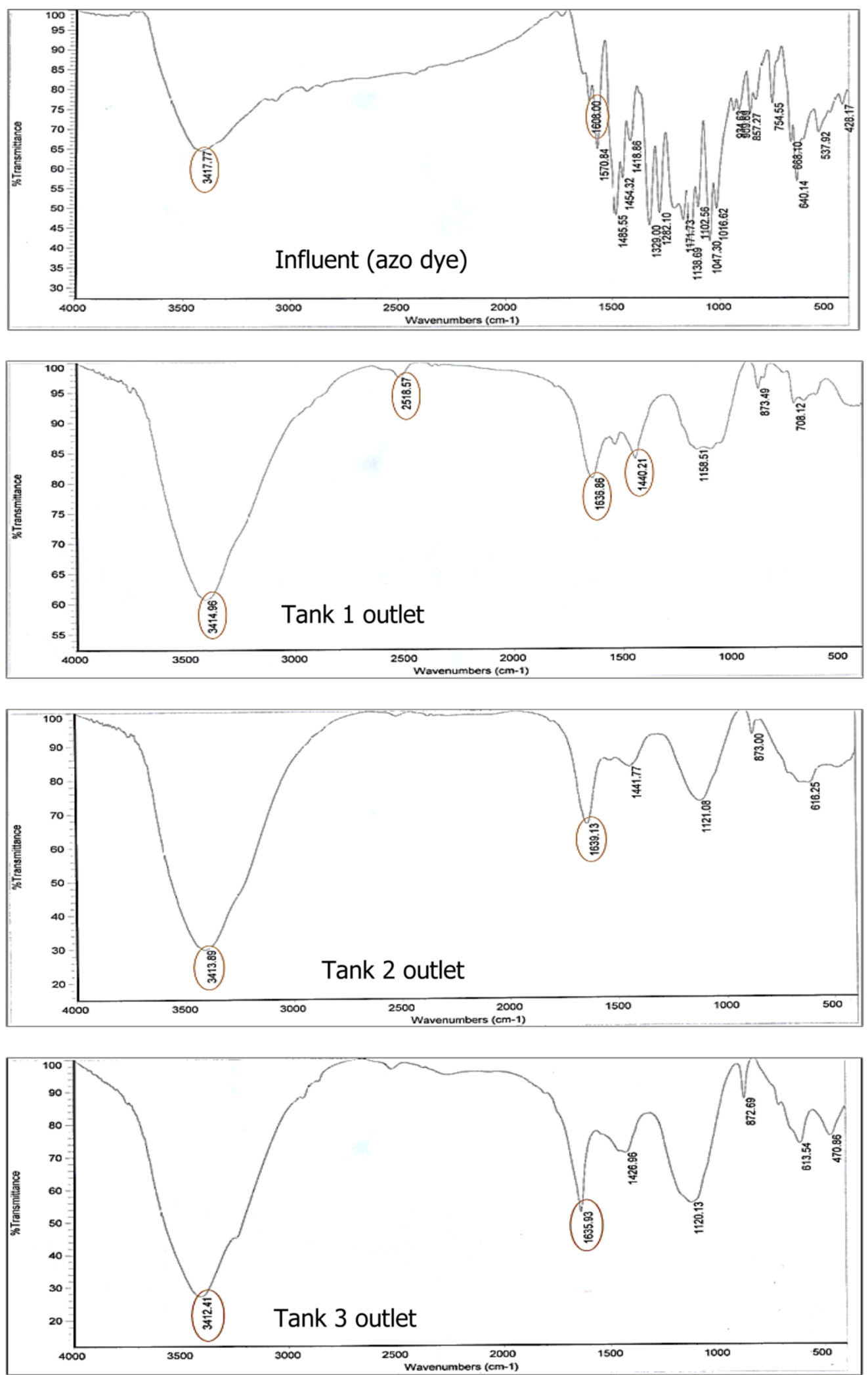

Fig. 2 Comparative FT-IR spectrum of azo dye and its degradation in inlet azo dye, Tank 1, Tank 2, and Tank 3

Morphoanatomical and phytotoxicity

The movement and biotransformation of azo dye in macrophyte's vegetative parts was evaluated in $E$. crassipes, $H$. verticillata, and $P$. stratiotes (Fig. 4). The dye-treated and non-dye-treated young roots, stems, petioles, and offsets were selected from macrophytes. Cross-sections were made for each vegetative part and observed under microscope with $\times 10$ magnification. The azo dye transportation, bioaccumulation, and morphological changes 
Table 1. The IR spectral data of the azo dyes and their complexes $\left(\mathrm{KBr}, \mathrm{cm}^{-1}\right)$

\begin{tabular}{|ll}
\hline Samples & Wavenumber $\mathrm{cm}^{-1}$ \\
\hline Influent dye & $-\mathrm{N}-\mathrm{H} 3417.77 \mathrm{~cm}^{-1}$ \\
solution & $-\mathrm{OH}$ stretching 3417 \\
& $-\mathrm{CH}$ stretching 1608 \\
Tank 1 Outlet & $-\mathrm{OH}$ stretching 3414 \\
& $-\mathrm{CH}$ stretching 2914 \\
& $-\mathrm{C}=$ O stretching 1637 \\
& $-\mathrm{C}-\mathrm{C}$ Symmetric stretching 1429 \\
& $-\mathrm{CH}$ bending 1371 \\
Tank 2 Outlet & $-\mathrm{OH}$ stretching 3413 \\
& $-\mathrm{CH}$ stretching 2901 \\
& $-\mathrm{C}=$ O stretching 1639 \\
& $-\mathrm{C}-\mathrm{C}$ Symmetric stretching 1431 \\
& $-\mathrm{CH}$ bending 1371 \\
Tank 3 Outlet & $-\mathrm{OH}$ stretching 3412 \\
& $-\mathrm{C}=$ O stretching 1635 \\
& $-\mathrm{C}-\mathrm{C}$ Symmetric stretching 1426 \\
&
\end{tabular}

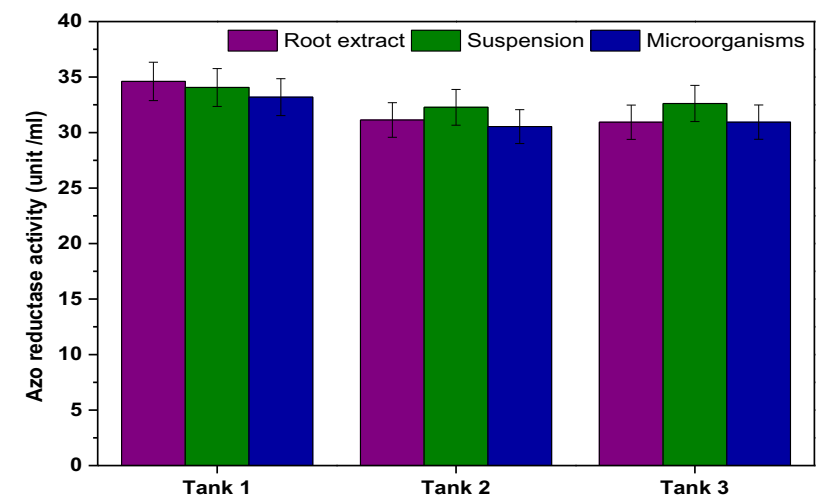

Fig. 3 Azo reductase enzyme activity of the root extract, microorganisms in suspension, and rhizosphere, each value is represented as mean of three replicates and statistical differences between values at a $5 \%$ level of significance

were not found in the epidermis, parenchyma cells, phloem, xylem, and other vascular bundles of dye treated when compared with non-dye-treated macrophytes. Morphological observations of dye-treated and control non-treated plant sections revealed no cellular morphological changes. It indicates that the metabolites formed during dye degradation were nontoxic in nature as the growth of the plant was not inhibited.

\section{Morphological toxicity analysis}

The aquatic toxicity was studied with 10 Gambusia affinis (length $=2.2 \pm 0.06 \mathrm{~cm}$; width $=2.5 \pm 0.014 \mathrm{~cm}$ ) selected randomly from Tank 3. These fishes were killed for analysis. Autopsy of fishes was done upon chronic exposure for RBC counts and blood smear. The RBC measurements made by a hemocytometer standardized with a micrometer scale as parallel magnification $(\times 10$ and $\times 100)$. The percentage of morphological RBCs was calculated by observing 100 RBCs in 20 microscopic fields $(\times 10$ and $\times 100)$ using an oil immersion and found that no morphological abnormalities were found in the RBC cells. Fish population was assessed for a physiological variation where there was no visible colour change observed on the skin layers.

\section{COD removal}

Co-substrate degradation based on COD removal was comparatively evaluated in the three tanks. The inlet was fed with a constant organic load of $250 \mathrm{mg}$ of COD/L. The co-substrate provided the energy required for the growth and survival of the microorganisms. Higher degradation was observed in Tank 1 with COD reduction from 250 to $110 \mathrm{mg}$ of COD/L (56\%) followed by Tank 2 (44 mg of COD/L; 60\%) and Tank 3 (34 mg of COD/L; 34\%) (Fig. 5a, b). TEWS in total contributed for $87 \%$ of COD removal efficiency. During the initial phase of operation, outlet COD from three Tanks varied between 190 and $120 \mathrm{mg}$ of COD/L, due to requirement of adaptability. During the initial stage of operation, plants showed stress and then with time adapted to the chemotrophic nature. The substrate degradation can be attributed to the co-existence of tri-phasic microenvironments viz., anoxic, aerobic, and anoxic in Tank 1, Tank 2, and Tank 3, respectively. The anoxic microenvironment in Tank 1 facilitates the mineralization/ reduction of the substrate by facultative bacteria. The floating aquatic plants grown as a mat on the surface of water, usually cause the water to be isolated from the atmosphere and result in the quiescence and hinderance of the gas transfer, creating anoxic conditions, particularly in Tank 1 . The quiescent condition also supports the system microenvironment for effective dye removal. Aerobic condition in the Tank 2 due to the submerged macrophytes facilitate the growth of aerobic microflora, which metabolize the reduced intermediates and are capable of absorbing nutrients and some organic compounds. As compared with floating macrophytes, it may be considered that the main removal mechanism is by bacteria rather than plant uptake particularly in Tank 2. Apart from oxygen release, the photosynthetic mechanism of the submerged plants provide symbiotic association, which positively influenced the overall treatment efficiency.

\section{System redox variation}

During decolourization, the $\mathrm{pH}$ of influent and effluent varied between 7 and 8 in each tanks. A marginal decrease in $\mathrm{pH}$ was observed in the outlet of Tank 1 compared with influent. There was a slight higher and consistency of $\mathrm{pH}$ observed in Tank 2 and Tank 3, respectively (pH 7.65 and 7.1) (Fig. 6a). In anaerobic microenvironment (Tank 1), azo dye reduction occurred which might have resulted in the breakdown of the azo bond subsequently forming respective aromatic amine intermediates. Due to these, amine compounds stability utilizes the protons, it reduces proton concentration and increases the $\mathrm{OH}^{-}$concentration in the aqueous solutions. This is attributed to the rising of $\mathrm{pH}$ which was maintained at near-neutral conditions, as well as anoxic microenvironment. The fluctuation of the $\mathrm{pH}$ will depend on the buffering capability of the water. However, Tank 2 and 3 showed marginally higher $\mathrm{pH}$ and values than the Tank 1, which might have influenced by the DO concentration. Most of the studies showed that the submerged macrophytes (Hydrilla) could decrease the anaerobisity due to producing the oxygen gas. The higher DO (>1 mg/L) facilitates the biodegradation and improves the effluents redox status. In general, nitrification process occurs at higher oxidative conditions in the Tank 2.

\section{Dissolved oxygen}

The DO concentration varied in the system during operation, based on the day $(12: 00 \mathrm{am})$ and night $(6: 30 \mathrm{pm})$ conditions (Fig. 6b). The inlet DO remained more or less constant near $2.1 \pm$ $0.1 \mathrm{mg} / \mathrm{L}$ during the operation. Tank 2 showed higher DO concentrations [morning, $5.8 \mathrm{mg} / \mathrm{l}$; night, $3.88 \mathrm{mg} / \mathrm{L}$ ] followed by Tank 3 (4.04 mg/L and $3.08 \mathrm{mg} / \mathrm{L})$, and Tank 1 showed least DO concentration $(<0.2 \mathrm{mg} / \mathrm{L})$, when measured during day and night time of operation. During night DO, values are relatively low due to the low photosynthetic activity. Tropical behavior based on DO concentration was engineered by the indigenous specific macrophytes induction in tanks. The microenvironments in Tank 1 lead to enrichment of specific anoxic consortia showed lowest DO 


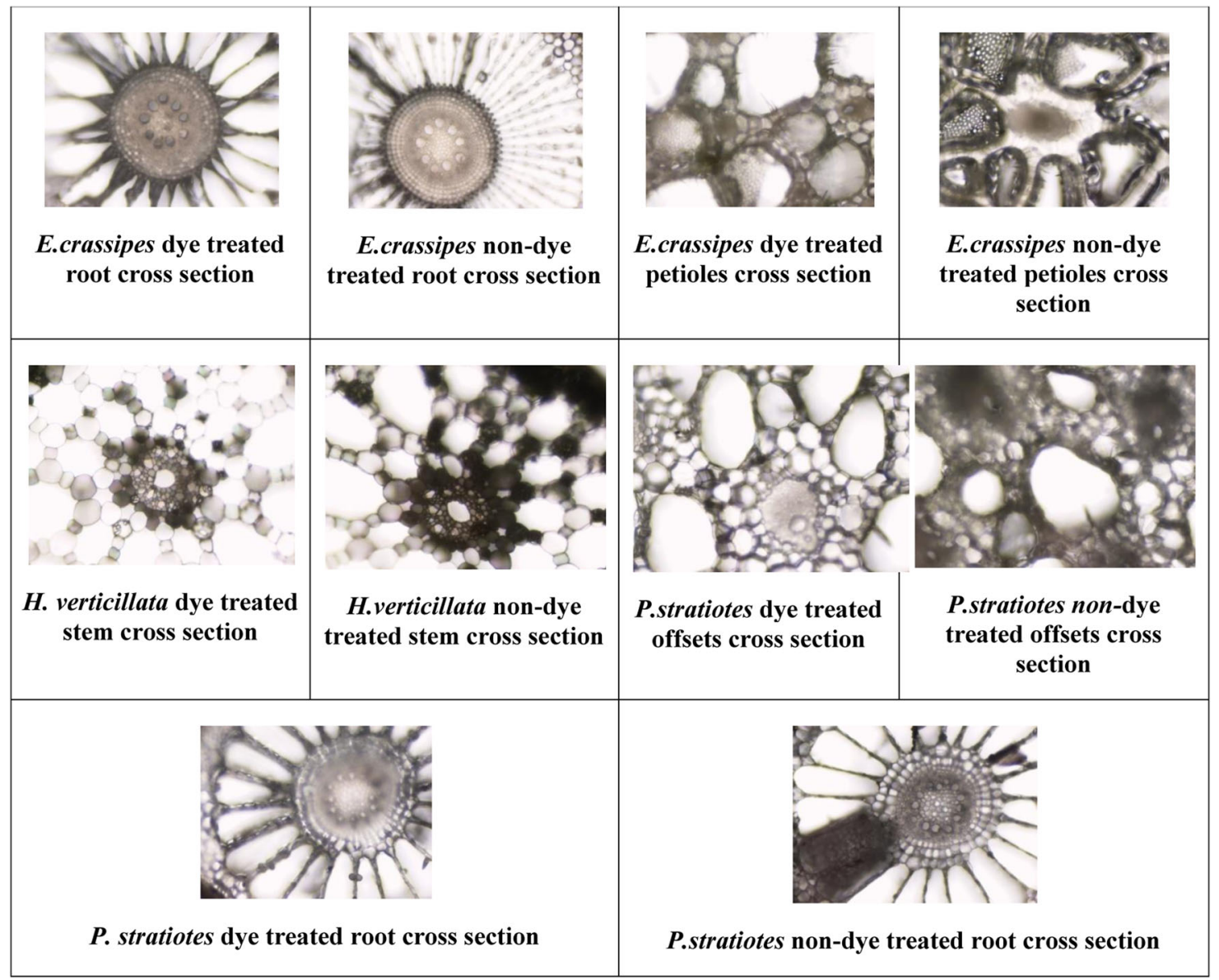

Fig. 4 Morphoanatomical and phytotoxicity analysis of the root, stem, petioles, and offsets of plants cross-sections in each tank when exposed and not exposed to dye

levels. The rapid growth nature of Eichhornia indicates the development of the anaerobic/anoxic conditions, which mediate the rapid decolorization of azo dye under an aerobic microenvironment, involving the reductive transformation of the azo cheomophoric system and forms the aromatic amine. These aromatic groups are substituted with the amino group, which does not have adsorption in UV region of the spectrum and results in the decolorization of wastewater. Higher DO present in the Tank 2 can detoxify the toxic aromatic amino compounds by the aerobic microenvironment. Sustainable $\mathrm{O}_{2}$ released by submerged Hydrilla in Tank 2 may help in enrichment of the aerobic bacteria, which facilitated the conversion of amines to nitrates by nitrification process. Tank 3 maintained the DO concentration for the growth of the fishes and aquatic plants. The outlet of the effluents have higher DO levels than the inlet to Tank 1. The presence of oxygen in the system facilitates the growth and provides habitat for flora and fauna of aquatic nature.

The results obtained from the TEWS system substantiate sustainable solution for effective azo dye-based wastewater treatment employing synergism of anaerobic and aerobic microenvironment simulated with near-natural conditions. Essential part of the study contributes significantly to color and COD removal, which is supported by FT-IR and UV-Vis multi-scan spectra. An overall efficiency of $76 \%$ of dye removal was achieved, with individual tanks removal efficiency accounting to $62 \%, 25 \%$, and $17 \%$ in Tank 1, Tank 2, and Tank 3, respectively. TEWS has the advantage of the tri-phasic microenvironment and flow connections that helps to mineralize azo dye by sequential redox reactions with anoxic, aerobic, and filtering mechanisms.

\section{METHODS}

Tri-phasic engineered free-floating wetland system

TEWS was designed with three rectangular tanks having dimensions of $55 \times 30 \times 30-\mathrm{cm}$ length, width, and height, using perplex sheets with the total/working volume of $50 / 35 \mathrm{~L}$ (free board of $5 \mathrm{~cm}$ ) as described elsewhere. ${ }^{25}$ The three tanks were placed on a customized stand with natural gradient of $15 \mathrm{~cm}$ allowing the flow with gravity (Fig. 7). The feed tank was kept at the highest point followed by the series of other tanks. The tanks were labeled from the top to bottom as Tank 1, Tank 2, and Tank 3 , respectively (Table 2 ). The tanks were provided with baffles to prevent cross discharge and to equalize the flow. Vents were provided at a distance of $5 \mathrm{~cm}$ from the top of the tank. The system was operated in continuous mode with a constant flow rate of $2 \mathrm{~L} / \mathrm{h}$. Tank 1 and Tank 2 were filled with sediment obtained from Nacharam lake, Hyderabad upto a height of $5 \mathrm{~cm}$ from the bottom, and Tank 3 was filled with fine sand.

\section{Macrophytes}

The microenvironment in three tanks were designed to simulate natural ecological conditions based on different hydroponic macrophytes, and Tank 1 was designed to house free-floating macrophytes (Eichhornia crassipes). It covers the water surface of the tank and helps to maintain anoxic microenvironment. Moreover, Eichhornia crassipes, owing to its strong tolerance to pollutants, develops a good fibrous root system, which is favorable for the growth of different microbial communities in the rhizosphere with rapid growth and reproduction. Tank 2 contains slender, submerged, perennial aquatic herbs (Hydrilla verticillata; Water thyme), which helps in maintaining aerobic condition in the tank by respiring underwater. The growth of these plants is very rapid and they contain a tuberous root system anchored to the sediment. Tank 3 was designed to have Pistia stratiotes (water cabbage) along with fish (Gambusia affinis) and snails (Cornu aspersum), which enables final water polishing by the filterfeeding action of snails and fish and consume the bacteria and planktons. 

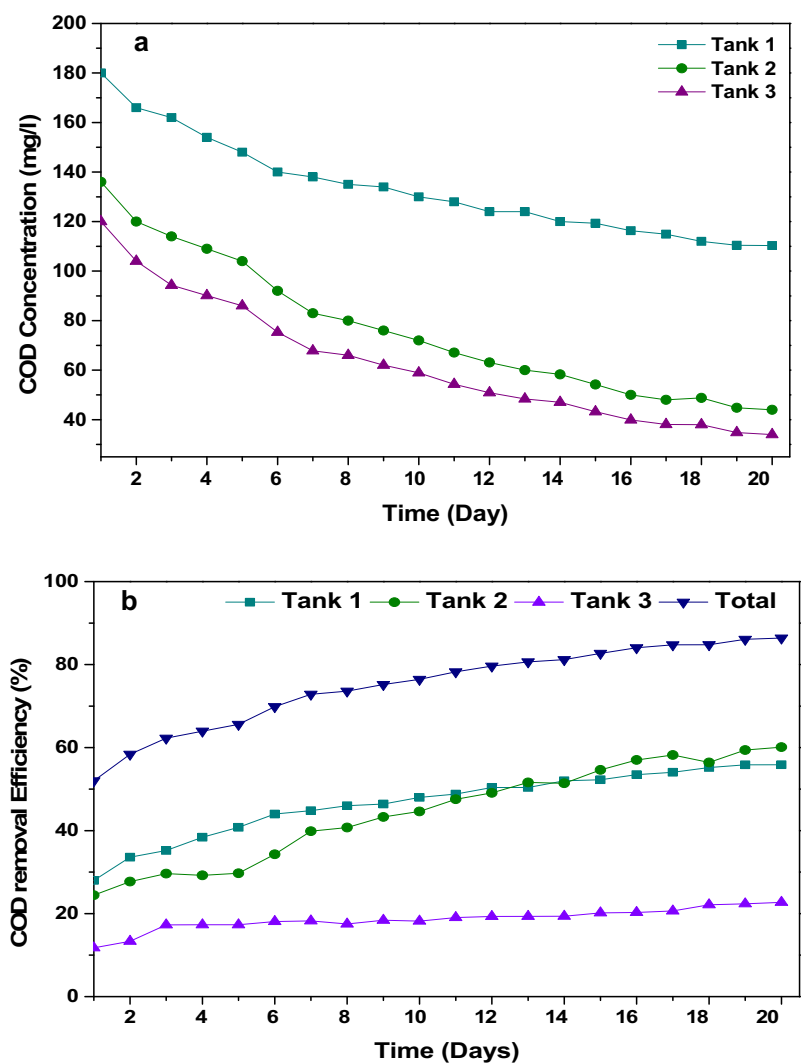

Fig. 5 Variations in the substrate removal monitored for Tank 1, Tank 2, and Tank 3 with respect to time, a chemical oxygen demand (COD) removal in concentration, b COD removal efficiency
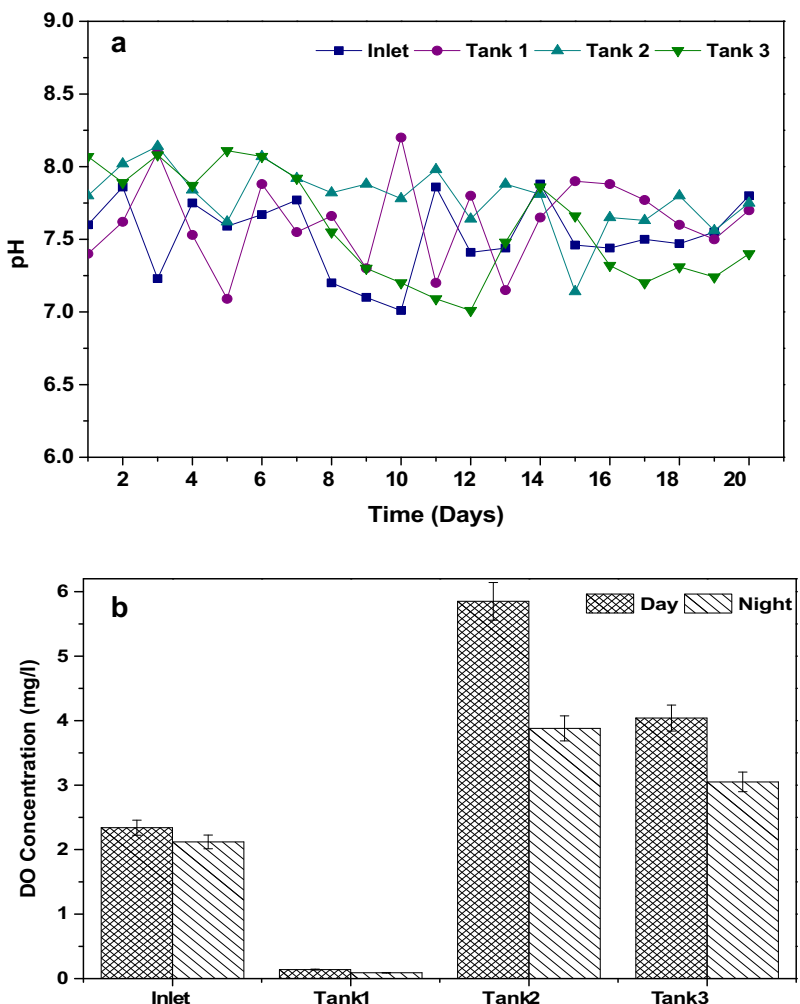

Fig. 6 Bioprocess monitoring in TEWS a pH in individual tanks, b dissolved oxygen profile in individual tanks, each value is mean of three replicates and statistically significant differences between values at a $5 \%$ level of significance

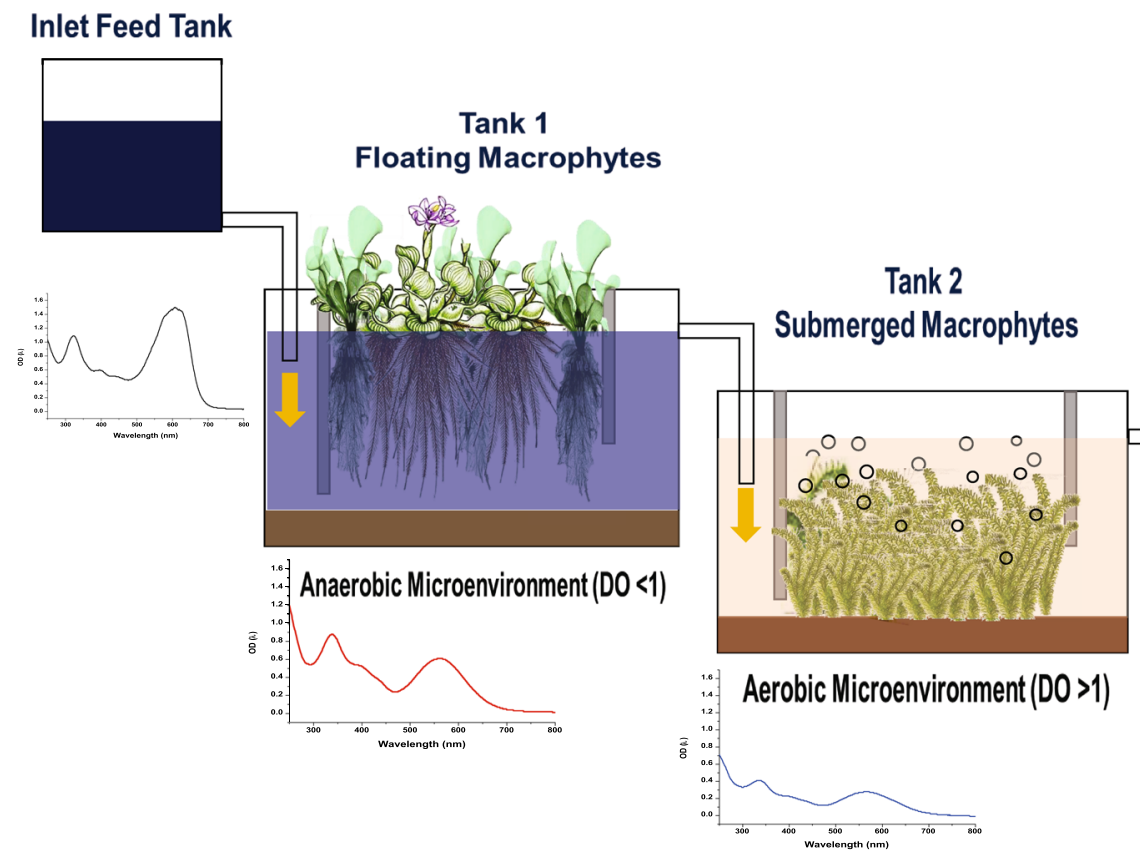

Tank 3

Filter-feeding based system

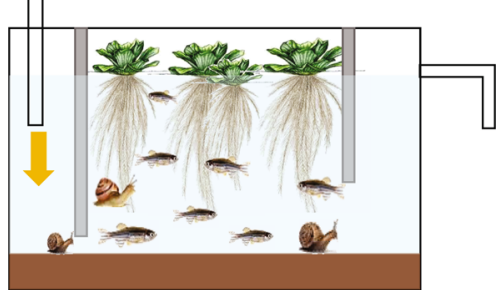

Filter feeders (DO >1)

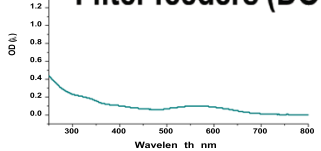

Fig. 7 Schematic representation of the TEWS system; Tank 1 grown with free-floating macrophytes (Eichhornia crassipes) helps to maintain the anoxic microenvironment. Tank 2 contains slender, submerged, perennial aquatic herbs (Hydrilla verticillata), which helps in maintaining aerobic conditions in the tank by respiring underwater. Tank 3 was designed to have Pistia stratiotes (water cabbage) along with fish (Gambusia affinis) and snails (Cornu aspersum), which enables final water polishing by the filter-feeding action of snails and fish and consume the bacteria and planktons. The spectra graphs represent the degradation of the dye from inlet in the tanks 
Table 2. Tri-phasic engineered wetland system with various types of biota along with the individual function of tanks

\begin{tabular}{|llll}
\hline Treatment system & $\begin{array}{l}\text { Type of system and } \\
\text { components }\end{array}$ & Functions & Advantages \\
\hline Tank 1 & $\begin{array}{l}\text { Floating macrophyte based } \\
\text { system with Eichhornia } \\
\text { crassipes }\end{array}$ & $\begin{array}{l}\text { To favors anoxic microenvironment and } \\
\text { enrich the anaerobic microbial consortia }\end{array}$ & $\begin{array}{l}\text { Fast growing, high nutrient uptake, the sponge- } \\
\text { type root system, creates low oxygen conditions } \\
\text { beneath the mat }\end{array}$ \\
Tank 2 & $\begin{array}{l}\text { Submerged macrophyte-based } \\
\text { system with Hydrilla verticillata }\end{array}$ & $\begin{array}{l}\text { To increase DO concentration in water and } \\
\text { enhaces the aerobic microbes }\end{array}$ & $\begin{array}{l}\text { High photosynthetic } \mathrm{O}_{2} \text { producer, a fast-growing } \\
\text { plant, provides a good habitat for aerobic bacteria } \\
\text { Tank } 3\end{array}$ \\
$\begin{array}{l}\text { Filter-feeding-based system } \\
\text { with Pistia stratiotes and fish }\end{array}$ & To enables final water polishing & $\begin{array}{l}\text { Removes the suspended particles, reduce } \\
\text { pathogenic microorganisms, insects larva }\end{array}$ \\
\hline
\end{tabular}

\section{Wastewater}

C.I.Acid Black 10B [4-amino-5-hydroxy-3-[(4-nitrophenyl) azo]-6-(phenyl azo)-2, 7-naphthalene disulfonic acid disodium salt, $\left.\mathrm{C}_{22} \mathrm{H}_{14} \mathrm{~N}_{6} \mathrm{O}_{9} \mathrm{~S}_{2} \mathrm{Na}_{2}\right]$ related to the azo group was used to prepare simulated dye wastewater (SDW) by dissolving $50 \mathrm{mg} / \mathrm{L}$ of dye in designed synthetic water $((\mathrm{g} / \mathrm{L})$ : glucose $0.25, \mathrm{NH}_{4} \mathrm{Cl} 0.5, \mathrm{KH}_{2} \mathrm{PO}_{4} 0.25, \mathrm{~K}_{2} \mathrm{HPO}_{4} 0.25, \mathrm{MgCl}_{2} 0.03, \mathrm{CoCl}_{2} 0.025$, $\mathrm{FeCl}_{3}$ 0.025, $\mathrm{ZnCl}_{2} 0.0115, \mathrm{NiSO}_{4} 0.050, \mathrm{CuCl}_{2} 0.0105, \mathrm{CaCl}_{2} 0.005$, and $\mathrm{MnCl}_{2}$ 0.015). Prior to feeding, $\mathrm{pH}$ of SDW was adjusted to $7.0 \pm 0.1$ using $1 \mathrm{~N} \mathrm{HCl} / \mathrm{NaOH}$.

\section{Operation}

TEWS was continuously operated with $50 \mathrm{mg} / \mathrm{L}$ of simulated azo dye-based wastewater with dissolved organic carbon load of $250 \mathrm{mg} / \mathrm{L}$ as a cosubstrate for a period of 90 days in a continuous mode with a constant flow rate of $2 \mathrm{~L} / \mathrm{h}$. The wastewater allowed to flow in series through Tanks 1,2 , and 3 by gravity, while the treated effluent from Tank 3 was used for gardening. After stabilization of the system performance (growth of the plant vegetation was stabilized), the last 20 days of operation data were reported in the communication. Harvesting of the aquatic plant biomass was done once in 20-25 days, depending on the growth. The degradation toxicity of treated dye-based wastewater in TEWS was evaluated by subjecting to fishes in Tank 3 throughout the experiment.

\section{Process monitoring}

To determine the decolorization efficiency, samples were withdrawn from TEWS systems at periodic time intervals during reactor operation. Samples were centrifuged $\left(10,000 \mathrm{rpm} ; 5 \mathrm{~min} ; 28^{\circ} \mathrm{C}\right)$ to remove suspended biomass with appropriate dilutions, and the absorbance was measured at $\lambda_{\max }$ of $618 \mathrm{~nm}^{42}$ using a spectrophotometer (Gene Quant 1300). Azo dye concentration was quantified from a standard curve, and the samples were analyzed for the changes in COD as per standard procedures. ${ }^{43}$ Azo reductase activity was determined to understand the reductive breakdown of azo bond in the dye molecule using a colorimetric method by estimating the extracellular azo reductase activity with NADH as cosubstrate. ${ }^{42,44}$ Reaction mixture constituting $600 \mu \mathrm{l}$ of sample, $600 \mu \mathrm{l}$ of test dye, $1.2 \mathrm{ml}$ of potassium phosphate buffer, and $7 \mathrm{mg} / \mathrm{mL}$ of $\mathrm{NADH}$ was incubated for $12 \mathrm{~h}$ at $37^{\circ} \mathrm{C}$. The absorbance of the overnight incubated reaction mixture was monitored at $\lambda_{\max }$ of $618 \mathrm{~nm}$. One unit of azo reductase accounts for the amount of enzyme required to decolorize $1 \mathrm{~mol}$ of dye per min. Process monitoring was observed with $\mathrm{pH}$ and DO as per APHA (4500-O) methods. The azo dye bonds were analyzed based on FT-IR spectra data from each tank inlet and outlet. Toxicity test was carried out through fish survivability analysis in treated dye wastewater with respective to each tank.

\section{DATA AVAILABILITY}

All data generated or analyzed during this study are included in this article.

\section{ACKNOWLEDGEMENTS}

The authors greatly acknowledge financial support from Department of Biotechnology (DBT), Government of India in the form of project (BT/PR18965/BCE/8/1401/ 2016). DKY duly acknowledge CSIR, New Delhi, for providing research fellowship. IICT Manuscript No. IICT/Pubs./2019/116

\section{AUTHOR CONTRIBUTIONS}

D.K.Y., P.R. and A.K.K. contributed executing the experiments and writing the paper equally. S.V.M. designed and supervised the experiments and associated in writing the paper.

\section{ADDITIONAL INFORMATION}

Competing interests: The authors declare no competing interests.

Publisher's note: Springer Nature remains neutral with regard to jurisdictional claims in published maps and institutional affiliations.

\section{REFERENCES}

1. Ong, S. A., Uchiyama, K., Inadama, D., Ishida, Y. \& Yamagiwa, K. Treatment of azo dye Acid Orange 7 containing wastewater using up-flow constructed wetland with and without supplementary aeration. Bioresour. Technol. 101, 9049-9057 (2010).

2. Pandey, A., Singh, P. \& lyengar, L. Bacterial decolorization and degradation of azo dyes. Int. Biodeterior. Biodegrad. 59, 73-84 (2007).

3. Venkata Mohan, S., Suresh Babu, P. \& Srikanth, S. Azo dye remediation in periodic discontinuous batch mode operation: evaluation of metabolic shifts of the biocatalyst under aerobic, anaerobic and anoxic conditions. Sep. Purf. Technol. 118, 196-208 (2013).

4. Venkata Mohan, S., Bhaskar, Y. V. \& Karthikeyan, J. Biological decolourisation of simulated azo dye in aqueous phase by algae Spirogyra species. Int. J. Environ. Pollut. 21, 211-222 (2014).

5. McMullan, G. et al. Microbial decolourisation and degradation of textile dyes. Appl. Microbiol. Biotechnol. 56, 81-87 (2001).

6. Venkata Mohan, S., Prasad, K. K., Rao, N. C. \& Sarma, P. N. Enzyme mediated degradation of acid azo dye in aqueousphase. Chemosphere 58, 1097-1105 (2005).

7. Venkata Mohan, S., ChandrasekharaRao, N., Prasad, K. K., Madhavi, B. T. V. \& Sarma, P. N. Treatment of complex chemical effluents by sequencing batch reactor (SBR) with aerobic suspended growth configuration. Process Biochem. 40, 1501-1508 (2005).

8. Yeruva, D. K., Chiranjeevi, P., Butti, S. K. \& Venkata Mohan, S. Self-sustained photocatalytic power generation using eco-electrogenic engineered systems. Bioresour. Technol. 260, 23-29 (2018).

9. Sponza, D. T. \& Isik, M. Toxicity and intermediates of Cl Direct Red 28 dye through sequential anaerobic/aerobic treatment. Process Biochem. 40, 2735-2744 (2005).

10. Venkata Mohan, S., Rao, N. C. \& Sarma, P. N. Simulated acid azo dye (Acid black 210) wastewater treatment by periodic discontinuous batch mode operation under anoxic-aerobic-anoxic microenvironment conditions. Ecol. Eng. 31, 242-25 (2007).

11. Venkata Mohan, S., Babu, V. L., Bhaskar, Y. V. \& Sarma, P. N. Influence of recirculation on the performance of anaerobic sequencing batch biofilm reactor (AnSBBR) treating hyper saline composite chemical wastewater. Bioresour. Technol. 98, 1373-1379 (2007).

12. Venkata Mohan, S., Babu, P. S., Naresh, K., Velvizhi, G. \& Madamwar, D. Acid azo dye remediation in anoxic-aerobic-anoxic microenvironment under periodic discontinuous batch operation: bio-electro kinetics and microbial inventory. Bioresour. Technol. 119, 362-377 (2012).

13. Nagendranatha Reddy, C., Naresh Kumar, A., Modestra, A. J. \& Venkata Mohan, S. Induction of anoxic microenvironment in multi-phase metabolic shift strategy during periodic discontinuous batch mode operation enhances treatment of azo dye wastewater. Bioresour. Technol. 165, 241-249 (2014).

14. Ojuederie, O. B. \& Babalola, O. O. Microbial and plant-assisted bioremediation of heavy metal polluted environments: a review. Int. J. Environ. Res. Public Health 14 1504 (2017). 
15. Patil, P., Desai, N., Govindwar, S., Jadhav, J. P. \& Bapat, V. Degradation analysis of Reactive Red 198 by hairy roots of Tagetes patula L. (Marigold). Planta 230, 725-735 (2009).

16. Ghodake, G. S., Telke, A. A., Jadhav, J. P. \& Govindwar, S. P. Potential of Brassica juncea in order to treat textile effluent contaminated sites. Int J. Phytorem 11, 297-312 (2009).

17. Cluis, C. P. Junk-greedy greens: phytoremediation as a new option for soil decontamination. BioTeach J. 2, 61-67 (2004)

18. Bestani, B., Nouredine, B., Baghdad, B., Mostefa, B. \& Ahmed., A. Methylene blue and iodine adsorption onto an activated desert plant. Bioresour. Technol. 99, 8441-8444 (2008).

19. Yalcuk, A. \& Ugurlu, A. Comparison of horizontal and vertical constructed wetland systems for landfill leachate treatment. Bioresour. Technol. 100, 2521-2526 (2009).

20. Harrington, C. \& Scholz, M. Assessment of pre-digested piggery wastewater treatment operations with surface flow integrated constructed wetland systems. Bioresour. Technol. 101, 7713-7723 (2010).

21. Saeed, T. \& Sun, G. A lab-scale study of constructed wetlands with sugarcane bagasse and sand media for the treatment of textile wastewater. Bioresour. Technol. 128, 438-447 (2013).

22. Saeed, T. \& Sun, G. A review on nitrogen and organics removal mechanisms in subsurface flow constructed wetlands: dependency on environmental parameters, operating conditions and supporting media. J. Environ. Manag. 112, 429-448 (2012).

23. Badhe, N., Saha, S., Biswas, R. \& Nandy, T. Role of algal biofilm in improving the performance of free surface, up-flow constructed wetland Bioresour. Technol 169, 596-604 (2014).

24. Guterstam, Bjoin Ecological engineering for wastewater and its application in New England and Sweden. Ecol. Engg. 6, 96-108 (1996).

25. Venkata Mohan, S., Mohanakrishna, G., Chiranjeevi, P., Dinakar, Peri \& Sarma, P. N. Ecologically engineered system (EES) designed to integrate floating, emergent and submerged macrophytes for the treatment of domestic sewage and acid rich fermented-distillery wastewater: evaluation of long term performance. Bioresour. Technol. 101, 3363-3370 (2010).

26. Kiran Kumar, A., Chiranjeevi, P., Mohanakrishna, G. \& Venkata Mohan, S. Natural attenuation of endocrine-disrupting estrogens in an ecologically engineered treatment system (EETS) designed with floating submerged and emergent macrophytes. Ecol. Eng. 37, 1555-1562 (2011).

27. Venkata Mohan, S., Mohanakrishna, G. \& Chiranjeevi, P. Sustainable power generation from floating macrophytes based ecological microenvironment through embedded fuel cells along with simultaneous wastewater treatment. Bioresour. Technol. 102, 7036-7042 (2011).

28. Oduma Howard, T. \& Odumb, B. Concepts and methods of ecological engineering. Ecol. Eng. 20, 339-361 (2003).

29. Carty, A., Scholz, M., Heal, K., Gouriveau, F. \& Mustafa, A. The universal design, operation and maintenance guidelines for farm constructed wetlands (FCW) intemperate climates. Biores. Technol. 99, 6780-6792 (2008).

30. Wilson, D. Fateful Harvest: The True Story of a Small Town, A Global Industry and a Toxic Secret. (Harper Collins, New York, 2001).

31. Brown, M. A. \& De Vito, S. C. Predicting azo dye toxicity. Criti. Rev. Environ. Sci. Technol. 23, 249-324 (1993).

32. Liu, G. et al. Enhancing survival of Escherichia coli by expression of azoreductase AZR possessing quinone reductase activity. Appl Microbiol Biotechnol. 80, 409-416 (2008).
33. Gonçalves, A. M., Mendes, S., de Sanctis, D., Martins, L. O. \& Bento, I. The crystal structure of Pseudomonas putida azoreductase-the active site revisited. FEBS J. 280, 6643-6657 (2013).

34. Kudlich, M., Keck, A., Klein, J. \& Stolz, A. Localization of the enzyme system involved in the anaerobic reduction of azo dyes by Sphingomonas sp.strain BN6 and effect of artificial redox mediators on the rate of azo dye reduction. Appl Environ. Microbiol 63, 3691-3694 (1997).

35. Liu, G., Zhou, J., Fu, Q. S. \& Wang, J. The Escherichia coli azoreductase Azo Ris involved in resistance to thiol-specific stress caused by electrophilic quinones. J. Bacteriol. 191, 6394-6400 (2009).

36. Ryan, A. et al. A novel mechanism for azo reduction. J. Mol. Biol. 400, 24-37 (2010a).

37. Ryan, A., Wang, C. J., Laurieri, N., Westwood, I. \& Sim, E. Reaction mechanism of azo reductases suggests convergent evolution with quinone oxidoreductases. Protein Cell 1, 780-790 (2010b).

38. Hervas, M. et al. ArsH from the cyanobacterium Synechocystis sp. PCC 6803 is an efficient NADPH-dependent quinone reducatse. Biochemistry 51, 1178-1187 (2012).

39. Ryan, A., Kaplan, E., Nebel, J. C., Polycarpou, E. \& Crescente, V. Identification of $\mathrm{NAD}(\mathrm{P}) \mathrm{H}$ quinone oxidoreductase activity in azo reductases from $\mathrm{P}$. aeruginosa: azoreductases and $\mathrm{NAD}(\mathrm{P}) \mathrm{H}$ quinone oxidoreductases belong to the same $\mathrm{FMN}$ dependent superfamily of enzymes. PLOS ONE 9, 98551 (2014).

40. Misal, S. A. \& Gawai, KachruR. Azoreductase: a key player of xenobiotic metabolism. Bioresour. Bioprocess 5, 17 (2018).

41. Komives, T. \& Gullner, G. Phase I xenobiotic metabolic systems in plants. Z. Nat. C. 60, 179-185 (2005).

42. Naresh Kumar, A., Reddy, C. N., Prasad, R. H. \& Venkata Mohan, S. Azo dye load shockon relative behavior of biofilm and suspended growth configured periodic discontinuous batch mode operations: critical evaluation with enzymatic andbioelectro catalytic analysis. Water Res. 60, 182-196 (2014).

43. APHA. Standard Methods for the Examination of Water and Wastewater. 20th ed (American Public Health Association/American Water Works Association/Water Environment Federation, Washington DC, USA, 1998).

44. Leelakriangsak, M. \& Borisut, S. Characterization of the decolorizing activity of azo dyes by Bacillus subtilis azoreductase AzoR1. Songklanakarin. J. Sci. Technol. 34, 509-516 (2012).

Open Access This article is licensed under a Creative Commons Attribution 4.0 International License, which permits use, sharing,
adaptation, distribution and reproduction in any medium or format, as long as you give appropriate credit to the original author(s) and the source, provide a link to the Creative Commons license, and indicate if changes were made. The images or other third party material in this article are included in the article's Creative Commons license, unless indicated otherwise in a credit line to the material. If material is not included in the article's Creative Commons license and your intended use is not permitted by statutory regulation or exceeds the permitted use, you will need to obtain permission directly from the copyright holder. To view a copy of this license, visit http://creativecommons. org/licenses/by/4.0/.

(c) The Author(s) 2019 